\title{
Aoristo)))))
}

International Journal of Phenomenology, Hermeneutics and Metaphysics

\section{Cristianismo em Kierkegaard: uma análise a partír de Exercício do crístianísmo}

\author{
Christianity in Kierkegaard: an analysis from the Exercise \\ of Christianity \\ Prof. Dr. Marcio Gimenes de Paula \\ Universidade de Brasilia - UNB'
}

\section{RESUMO}

O objetivo do presente artigo é investigar a temática do cristianismo exposta por Kierkegaard na obra $O$ Exercício do cristianismo. $O$ artigo segue a divisão da obra de Kierkegaard e igualmente dividese em três partes: o convite, o escândalo e a majestade divina. Após tais reflexões, há uma conclusão final.

\section{PALAVRAS-CHAVE}

Cristianismo; Kierkegaard; Filosofia da religião; Filosofia contemporânea

\section{ABSTRACT}

The aim of the present article is to investigate, in a first moment, the subject of the Christianity exposed by Kierkegaard in the work Practice in Christianity. The article follows the division of Kierkegaard's work and is equally divided into three parts: the invitation, the scandal and the divine majesty. After such reflections, there is a final conclusion.

\section{KEY WORDS}

Christianity; Kierkegaard; Philosophy of Religion; Contemporary philosophy

\footnotetext{
1E-mail: marciogimenes@unb.br, Orcid: https://orcid.org/0000-0002-5991-5710
}

Marcio Gimenes de Paula Toledo, v. 4, n'2 (2021) p. 200-218 


\section{Aoristo)))))}

International Journal of Phenomenology, Hermeneutics and Metaphysics

\section{INTRODUÇÃO \\ O CRISTIANISMO DE O EXERCÍCIO DO CRISTIANISMO DE KIERKEGAARD}

A obra kierkegaardiana $O$ Exercício do cristianismo foi publicada em 1850. Seu pseudônimo autor é Anti-Climacus, o mesmo que também havia assinado A Doença Mortal em 1849, ou seja, apenas um ano antes. Para os que possuem alguma leitura ou familiaridade com os pseudônimos kierkegaardianos, ele imediatamente nos faz lembrar outro pseudônimo autoral do pensador dinamarquês: Johannes Climacus, autor das obras Migalhas filosóficas (1844), Pós-Escrito às Migalhas filosóficas (1846) (KIERKEGAARD, 1995; 2013)2', É preciso duvida de tudo (1842-1843).

O título da obra, no original dinamarquês, é Indøvelse $i$ Christendom (KIERKEGAARD, 1850). A rigor, pode-se traduzi-lo em português como Exercício do cristianismo, mas há sempre implícita a ideia de prática e mesmo de escola no sentido de algo que se pode aprender. Curiosamente, a tradução americana dos Hong opta pelo título Practice in Christianity (KIERKEGAARD, 1991), a tradução italiana de Cornélio Fabro opta por Esercizio dei cristianesimo (KIERKEGAARD, 1971), a tradução francesa de Tisseau prefere L'École du christianisme (KIERKEGAARD, 1963), e a tradução espanhola de Demétrio Rivero escolhe o título Ejercitación del cristianismo (KIERKEGAARD, 2009). O título da obra não deixa de nos remeter aos clássicos da espiritualidade cristã como, por exemplo, Os Exercícios espirituais de Santo Inácio de Loyola (2000) e a Imitação de Cristo de Thomas Kempis (1987), dentre outros.

Na verdade, não é nem mesmo necessário possuir alguma familiaridade com a estratégia pseudonímica kierkegaardiana para perceber algo que salta aos olhos: um pseudônimo parece, ao menos num primeiro e genérico exame, colocar-se em oposição ao outro, isto é, um pseudônimo é Climacus, o outro é Anti-Climacus.

Climacus é um pseudônimo cuja psicologia é marcada por uma tentativa de explicar ou demonstrar o cristianismo ao modo grego e filosófico. Por isso, em suas produções destaca-se tal aspecto ainda que, no decorrer delas, ele mesmo parece ir se convencendo de que o cristianismo enquanto fenômeno não pode ser totalmente compreendido ao modo grego ou visto pela mais absoluta razão moderna.

Já Anti-Climacus, autor de A Doença Mortal e de Exercício do cristianismo, se constitui naquilo que o pensador dinamarquês irá denominar nos seus Diários como o "cristão por excelência" e assim, em oposição a um dado ceticismo de Climacus, Anti-Climacus parece afirmar o cristianismo no mais alto grau o que, inclusive, faz o próprio Kierkegaard curiosamente pensar que ele, pessoalmente, seria uma espécie de pensador que oscilaria entre o ceticismo de Climacus e a mais alta afirmação do cristianismo de Anti-Climacus:

\footnotetext{
${ }^{2}$ A rigor deve-se esclarecer que o Pós-Escrito é um obra pseudonímica, mas Kierkegaard agrega a ela o seu nome, o que não ocorre com as demais aqui listadas.
} 


\section{Aoristo)))))}

International Journal of Phenomenology, Hermeneutics and Metaphysics

Johannes Climacus e Anti-Climacus têm várias coisas em comum; mas a diferença é que enquanto Johannes Climacus se coloca tão baixo que chega a dizer que não é cristão, podemos detectar em AntiClimacus que ele considera a si mesmo como um cristão num grau extraordinariamente alto... eu mesmo me colocaria acima de Johannes Climacus, abaixo de Anti-Climacus (KIERKEGAARD, 1967-1978, vol VI, p. 6433).

Deve-se, contudo, ter cautela aqui, pois o que parece se estabelecer no jogo dos dois pseudônimos é mais uma relação dialética do que uma mera entre oposição entre eles. Além disso, a cautela também é necessária para perceber que, no pensamento kierkegaardiano, ser cristão no "mais alto grau" não implica em abdicar do pensamento, o que pode ser comprovado, por exemplo, numa análise de $A$ Doença Mortal, onde o pseudônimo Anti-Climacus lida com altíssimas questões sobre o eu, com a herança idealista germânica e o pensamento grego antes de adentrar propriamente nos temas da vontade e do pecado tais como pensados pelo cristianismo. Por essas razões, $O$ Exercício do cristianismo é, no fundo, uma continuidade, com outra linguagem, dos mesmos problemas colocados em A Doença Mortal, tal como, quiçá, O Pós-Escrito é a retomada dos temas já postos nas Migalhas filosóficas e, notadamente, de questões que ficaram abertas e não puderam ser respondidas.

O Exercício do cristianismo possui três grandes divisões. Na primeira delas destaca-se o tema do convite. O tema é assumidamente extraído dos Evangelhos, mais especificamente da passagem de Mateus 11:28-30, onde se pode ler o convite feito pelo Cristo a todos os homens: "Venham a mim, todos os que estão cansados e sobrecarregados, e eu lhes darei descanso. Tomem sobre vocês o meu jugo e aprendam de mim, pois sou manso e humilde de coração, e vocês encontrarão descanso para as suas almas. Pois o meu jugo é suave e o meu fardo é leve" (BÍBLIA, 2020). Assim, se o Zaratustra nietzschiano parece ser um livro "para todos e para ninguém", o tema de $O$ Exercício do cristianismo é exatamente o oposto, ou seja, uma espécie de livro para todos e para qualquer um, onde todos estão convidados.

Já a segunda parte da obra trata de um problema central no cristianismo: o tema do escândalo. Aqui Anti-Climacus desenvolve uma exposição minuciosa do tema do ponto de vista do cristianismo e o aborda em consonância com outro aspecto central da sua essência, a saber, o tema do Deus-Homem.

Por fim, a terceira parte da obra tratará do tema da majestade divina, almejando compreender aqui como ocorre, na interpretação cristã, o rebaixamento de Deus até o último dos mortais. Assim, um tema muito presente será a discussão entre a Igreja triunfante, conceito muito criticado por Kierkegaard no decorrer de toda a sua obra, e o conceito de Igreja militante, tema muito caro às teses kierkegaardianas de recuperação do autêntico cristianismo. Passemos agora, portanto, a uma melhor observação de cada uma das partes da obra. 


\section{Aoristo)))))}

International Journal of Phenomenology, Hermeneutics and Metaphysics

\section{CONVITE}

Há uma expressão, logo no início da primeira parte que, muitas vezes, passa desapercebida na análise do Exercício do cristianismo. Ali, entre o mote chave "Venham a mim todos os que estão cansados e sobrecarregados, que eu vos aliviarei" e o nome do pseudonímico autor, há a seguinte expressão: "para despertamento e interiorização". Em outras palavras, um objetivo do autor da obra é que seus leitores sejam pessoas despertas e atentas aos problemas da sua interioridade, isto é, que compreendam o cristianismo em tal esfera.

Igualmente aparece uma expressão latina procul o procul este profani que pode ser traduzida como "afastem-se, oh afastem-se daqui profanos". Em outras palavras, a expressão latina parece anunciar uma clara oposição às coisas da temporalidade do mundo dos homens e, por isso, estabelece a distinção entre as coisas sagradas e as coisas profanas.

A despeito da obra ser pseudonímica, e assinada por Anti-Climacus, Kierkegaard soma-se a ela como editor, tal como fizera no Pós-Escrito às Migalhas filosóficas com Climacus. Por isso, o pensador escreve um prólogo, cujas primeiras linhas são enfáticas: "Neste escrito, proveniente do ano de 1848 , a exigência de ser cristão é forçada por um pseudônimo até o mais alto grau de idealidade" (KIERKEGAARD, 2009, p. 29). Desse modo, o conceito de cristão é, aos olhos do autor dinamarquês, uma tarefa impossível ao homem pelos seus próprios esforços. Em outras palavras, o cristianismo é um ideal e o que sua reflexão talvez almeje responder é como se pode efetivar tal ideal. Alguns anos antes, mais precisamente em 1841, Feuerbach, um pensador muito admirado por Kierkegaard, escreve sua Essência do cristianismo e ali tenta cabalmente demonstrar que o cristianismo é um projeto totalmente humano. Nesse sentido, a obra kierkegaardiana é uma resposta ao pensador alemão, na medida em que vai exatamente na contramão de tal empreendimento.

Depois do prólogo, a obra começa, de modo mais efetivo, com uma invocação que, na verdade, pode ser tomada como uma espécie de oração, coisa que, aliás, ocorre em todos os capítulos da obra. Ali é dito: "Cumpriram-se já dezoito séculos desde que Jesus Cristo andou pela terra" (KIERKEGAARD, 2009, p. 31). Em outras palavras, aparece o traço temporal, isto é, o cristianismo é um fenômeno também histórico ocorrido - no caso de Kierkegaard - já há dezoito séculos. Por isso, não despropositadamente uma outra palavra importante nesta invocação é exatamente a palavra "contemporâneo". Percebemos aqui, desse modo, o cristianismo como um fenômeno relacionado com o contemporâneo e, assim, com o tempo. Tal tese sempre mereceu extremo cuidado de Kierkegaard e, se observarmos atentamente, ela já aparece em outras obras anteriores ao Exercício do cristianismo. Nas Migalhas filosóficas, por exemplo, o capítulo IV leva o título "a situação do discípulo contemporâneo" e ali se discute tal questão. Ou seja, em que medida o cristianismo pode ser um fenômeno histórico mas, ao mesmo tempo, possuir algo que transcende o histórico

\footnotetext{
${ }^{3}$ A obra foi efetivamente publicada em 1850, a despeito aqui da menção a 1848.
} 


\section{Aoristo)))))}

\section{International Journal of Phenomenology, Hermeneutics and Metaphysics}

ou, no linguajar kierkegaardiano de O Conceito de angústia, "o instante é aquela ambiguidade em que o tempo e a eternidade se tocam mutuamente" (KIERKEGAARD, 2010, p. 96).

Também a obra Pós-Escrito às Migalhas filosóficas abordará com especial atenção o problema histórico do cristianismo e sua relação com o tema da eternidade, tal como já fora posto pelas Migalhas filosóficas. Assim, o tema que retorna agora no Exercício do cristianismo é, na realidade, algo que nunca esteve ausente das reflexões kierkegaardianas. Curiosamente a pergunta que ele almeja responder tem uma dupla face, isto é, além do cristianismo ser um fenômeno histórico e, ao mesmo tempo, possuir uma relação com a eternidade, cabe perceber que aquilo que o legitima não pode apenas ter sido a vivência daquele que crê com o fenômeno pois, nesse caso, os seguidores que conviveram com Cristo ou com discípulos seriam tomados em mais alto grau do que aqueles que aderiram posteriormente ao cristianismo. Contudo, como o pensador já suspeitava nas Migalhas filosóficas, tal coisa criaria um cristianismo com duas categorias, a saber, o cristianismo dos contemporâneos de Cristo e o cristianismo dos pósteros. Ainda mais grave: estabeleceria uma distinção qualitativa entre eles, visto que o primeiro grupo seria mais autêntico e autorizado que o segundo. Tal coisa não pode ocorrer só pena do cristianismo não possuir efetivamente validade e não ser compreendido na esfera adequada, isto é, a do espírito. Assim, o problema aqui percebido é bastante marcante da filosofia do século XIX que, por inspiração hegeliana, julgava que compreender o cristianismo seria compreender a sua história. Por isso, tanto Climacus nas suas reflexões, como AntiClimacus em $O$ Exercício do cristianismo, terão que se debruçar não sobre o problema histórico do cristianismo, mas antes sobre o "tornar-se cristão" e, portanto, terão que abordar o problema dos indivíduos em sua subjetividade.

Além do traço da contemporaneidade, chama atenção no prólogo da obra, o traço do escândalo. Anti-Climacus nota que o cristianismo possui um componente escandaloso. A celebre sentença paulina pensa que o cristianismo é escândalo para os judeus, na medida em que rompe com prescrições legais e loucura para os gentios, na medida em que não se adequa aos critérios da racionalidade grega (1 Coríntios 1: 1825). Por isso, é um imenso desafio ao autêntico cristianismo não se escandalizar e o pseudônimo autor aponta tal coisa como uma espécie de desejo diante de algo que não podemos alcançar pelos próprios méritos ou pelo próprio esforço.

Curiosamente, parece ser exatamente por isso que a sentença bíblica escolhida para a reflexão disserta tão enfaticamente sobre o tema do esforço e aponta que Cristo seria uma espécie de alívio para os que estão cansados, sobrecarregados. Através de uma sofisticada argumentação literária, Anti-Climacus parece ressaltar, já nas primeiras páginas do seu texto, dois projetos. $\mathrm{O}$ primeiro deles, herdado da filosofia grega e socrática, parece afirmar a completa autonomia humana e, nesse sentido, o homem alcançaria a verdade pelos seus próprios esforços. Assim, o projeto iluminista do século XIX, que Kierkegaard conhece bem e critica, é herdeiro intelectual de tal tradição. $\mathrm{O}$ oposto de tal concepção seria o projeto do cristianismo que, uma vez rompido com a verdade por causa do pecado, acredita que somente

$$
\begin{array}{r}
\text { Marcio Gimenes de Paula } \\
\text { Toledo, v.4, n*2(2021) p. 200-218 }
\end{array}
$$




\section{Aoristo)))))}

\section{International Journal of Phenomenology, Hermeneutics and Metaphysics}

pela salvação de um totalmente outro que - em gesto gracioso e amoroso - salva toda a humanidade, o homem poderá reencontrar-se com a verdade com a qual ele mesmo rompeu em gesto voluntário. Desse modo, nas primeiras páginas do Exercício do cristianismo aparece um claro embate entre a salvação e o projeto cristão em oposição ao homem completamente autônomo do projeto iluminista. Logo, não parece despropositado o apelo do escritor para que aqueles que estão cansados e não conseguiram alcançar as coisas por esforço próprio depositem agora suas pesadas cargas nos ombros daquele que lhes pode efetivamente ajudar e servir de abrigo.

Logo após o convite, surge outro problema. Quem é aquele que convida? Em outras palavras, quem é aquele que diz poder aliviar as nossas cargas e os nossos sofrimentos? Anti-Climacus percebe, com argúcia, que não é indiferente quem é aquele que faz o convite. Os homens são convidados por Jesus Cristo mas, ainda assim, a resposta não é plenamente satisfatória, pois resta agora saber como é esse Cristo que convida os homens, pois dizer que somos convidados por Cristo ainda não se resolve plenamente a questão. Segundo ele, as coisas mudam radicalmente se o convite for feito pelo Cristo majestoso, sentado à mão direita de Deus Pai ou se for feito pelo Cristo rebaixado, aquele que foi humilhado: "Quem é o que convida? Jesus Cristo. Que Jesus Cristo? O Cristo que está sentado com majestade à direita do Pai? Não. A partir da majestade Ele não disse nenhuma palavra. Portanto é precisamente Jesus Cristo em sua humilhação, o que disse essas palavras" (KIERKEGAARD, 2009, p. 49).

Tal questão é absolutamente central na história do cristianismo e no pensamento kierkegaardiano. Já no Pós-Escrito às Migalhas filosóficas, Climacus almejava distinguir entre duas religiosidades a $\mathrm{A}$ e a $\mathrm{B}$, deixando claramente enfatizada sua predileção pela religiosidade $\mathrm{B}$, aquela próxima do cristianismo militante e em oposição ao cristianismo triunfante da religiosidade A. Por isso, o tema do cristianismo majestoso e triunfante é um tema central das reflexões kierkegaardianas e a ele se opõe o tema do Cristo humilhado e da religiosidade militante. Também nas Migalhas filosóficas, Climacus faz menção à situação do servo sofredor, já presente nas profecias de Isaías no contexto judaico, o que o aproxima, portanto da fé militante e do Cristo humilhado, tal como será exposto e defendido aqui pelo pseudonímico Anti-Climacus nas teses do Exercício do cristianismo.

A reflexão kierkegaardiana está colocada no cerne do século XIX e tal período, como é notório, encontra-se marcado pelas discussões acerca do cristianismo como história ou, talvez melhor pontuando, acerca da percepção do quanto a investigação acerca da história do cristianismo pode ser, talvez, compreendida como a própria essência do cristianismo. Tal reflexão aparece desde Hegel nos seus escritos como, por exemplo. A Vida de Jesus e em autores pós-hegelianos como David Strauss, igualmente autor de uma Vida de Jesus. A mesma reflexão pode ser percebida em uma série de autores do século XIX como Bruno Bauer, Franz Overbeck e, de certo modo, até mesmo no já citado Ludwig Feuerbach, dentre tantos outros.

Anti-Climacus parece enfático ao recusar a história como via de acesso ao cristianismo. Curiosamente, tal postura o aproximaria até mesmo de Nietzsche não 


\title{
Aoristo)))))
}

International Journal of Phenomenology, Hermeneutics and Metaphysics

propriamente naquilo que concerne ao cristianismo, mas sim na recusa da história, uma vez que o pensador alemão também defende, no seu célebre ensaio Sobre a utilidade e a desvantagem da história para a vida, uma postura bastante crítica em relação aquilo que pode efetivamente fazer a história e, desse modo, fazendo uma contraponto com o seu tempo. Vejamos o que diz o texto kierkegaardiano respondendo a indagação de se seria possível sabermos algo de Cristo por meio da história:

\begin{abstract}
Não. E por que não? Porque, em geral, nada pode 'saber-se' acerca de Cristo, ele é o paradoxo, objeto da fé, existe somente para a fé. Mas visto que toda comunicação histórica é comunicação do 'saber', pela história não pode chegar-se a saber nada sobre Cristo. Pois se se alcança saber pouco ou muito ou algo acerca Dele, deixa de ser o que é em verdade... A história faz de Cristo outra coisa do que em verdade era. Assim pois, se chega a saber pela história muito acerca de Cristo? Não, não é acerca de Cristo, já que sobre Ele nada se pode saber. Ele é somente objeto de fé (KIERKEGAARD, 2009, p. 51).
\end{abstract}

Há aqui algo que merece destaque na reflexão kierkegaardiana: a história, notadamente como compreendia no século XIX é uma ciência e, portanto, liga-se ao saber. Cristo é objeto da fé e não do saber. Assim, ele representa exatamente o paradoxo, isto é, o momento em que o saber não consegue mais avançar no campo especulativo. Tal reflexão já havia aparecido também nas Migalhas filosóficas e, com especial ênfase no Pós-Escrito às Migalhas filosóficas, onde a fé e o saber são claramente tomados como aspectos distintos. Por isso é que também uma das perguntas colocadas na sequência de tal reflexão no Exercício do cristianismo é exatamente se seria possível demonstrar-se pela história que Cristo é também Deus, o que, como se pode supor, se tornará impossível de demonstrar.

No século XIX falava-se muito também das consequências de Cristo como mais importantes do que a sua própria vida. Anti-Climacus rechaça tal tese pois, segundo seu entender, se isso fosse verdade "então Cristo seria somente um homem" (KIERKEGAARD, 2009, p 55). Entra aqui um aspecto muito central de toda a discussão cristológica. Por um lado, a divindade de Cristo; por outro, a sua humanidade. Aos olhos de Anti-Climacus não se trata de obscurecer ou eliminar a humanidade de Cristo mas, ao mesmo tempo, não se pode excluir da discussão igualmente a perspectiva divina do Cristo pois, em contrário, ele seria apenas um homem e não o Redentor e Salvador da humanidade. É nesse sentido que também podemos compreender, aos olhos do pseudônimo, que não pode haver plena comparação entre o sofrimento dos homens e o sofrimento de Cristo, visto que este nunca foi acidental e nem sem propósito. Se a história e o saber prevalecem como absolutos, parece "que o cristianismo se converteu assim em paganismo" (KIERKEGAARD, 2009, p 59), havendo também se perdido, com o passar do tempo aquilo que Kierkegaard também gostava de enfatizar como "mil e oitocentos anos se 


\section{Aoristo)))))}

\section{International Journal of Phenomenology, Hermeneutics and Metaphysics}

passaram", ou seja, o paradoxo e o próprio conceito de cristianismo. Por isso, o autor é enfático: "A cristandade aboliu o cristianismo sem sequer dar-se conta; a consequência é; deve-se fazer algo, que se deve tentar novamente introduzir o cristianismo na cristandade" (KIERKEGAARD, 2009, p 60).

A categoria aqui levantada é muito instigante. Trata-se da reintrodução do cristianismo na própria cristandade, algo como um tipo de missão interna. Não se trata mais do missionário que parte para proclamar o cristianismo aos que não o conhecem, mas de sua reintrodução no meio daqueles que afirmavam serem cristãos. Tal característica parece sempre haver marcado o próprio cristianismo, isto é, uma pergunta ética e moral a fim de inquirir se, de fato, se o cristianismo está sendo levado adiante por aqueles se denominam cristãos. Por isso, em seus fascículos inacabados de $O$ Instante, escritos entre 1854 e 1855, a questão parece haver chegado ao ápice na reflexão kierkegaardiana e, a essa, acrescenta-se também aspectos da ironia socrática, tão bem conhecida pelo autor dinamarquês desde os seus primeiros escritos. Assim, Sócrates também será a fonte de inspiração para a crítica final à cristandade e à cultura da época pois, tal como fizera o ateniense, os escritos kierkegaaridianos parecem cobrar dos seus interlocutores que lhes explique efetivamente em que consiste o cristianismo. Sem dúvida, tudo isso já está presente nos escritos de Climacus e Anti-Climacus, pseudônimos que oscilam entre o ceticismo e a crença.

Aqui, no caso do Exercício do cristianismo, o problema não parece restrito apenas aos limites da história, mas também ao convite feito pela divindade aos homens. Contudo, o problema também não está restrito apenas ao convite, mas aquele que o faz. Em outras palavras, aquele que convida não é o Cristo exaltado, mas o Cristo humilhado. A primeira parte de sua vida mostra que ele se fez contemporâneo dos homens, viveu entre eles, ainda que fosse Deus. A segunda parte de sua vida espelha aquilo que a teologia denominou como "o Cristo da fé", isto é, aparece aqui a oposição entre o que foi o Jesus histórico (que viveu numa época, num contexto e entre determinados homens) e o que foi o Cristo da fé (salvador e redentor da humanidade) $)^{4}$.

Aos olhos de Anti-Climacus, o escândalo reside no fato de que aquele que convida é o próprio Deus sendo, ao mesmo tempo, o mais rebaixado dos homens. Nisso residiria o paradoxo e o escândalo. Não apenas o seu convite é recusado, mas aquele que convida é também morto e perseguido por não apresentar ou aparentar nenhuma das condições exigidas e esperadas de quem faz tal convite. Deve-se atentar para o fato de que existe um convite justamente porque os homens, por conta própria, já não podem mais alcançar o fim de sua opressão, redenção ou salvação. Assim, há no convite também uma tese: o homem é pecador e o pecado é uma categoria kierkegaardiana importante em tal horizonte. Aliás, a mesma categoria que já foi explorada - com outros olhares - nas obras O Conceito de angústia, Migalhas filosóficas e Pós-Escrito às Migalhas filosóficas. Para nos atermos as obras assinadas pelo mesmo Anti-Climacus, cabe mencionar que o conceito de pecado será central na obra

\footnotetext{
${ }^{4}$ Um exemplo cabal desse tipo de explicação encontra-se nas teses de Bultmann (1999).
} 


\title{
Aoristo)))))
}

International Journal of Phenomenology, Hermeneutics and Metaphysics

publicada um ano antes do Exercício do cristianismo, isto é, A Doença Mortal. Ali, o mesmo pseudônimo após dissertar sobre o tema do eu e da consciência, temas tão centrais do idealismo, alcança a discussão sobre o conceito de queda, ruptura, pecado e, nesse sentido, chega até mesmo a questionar-se sobre o que seria um hipotético conceito socrático de pecado que, obviamente, não poderia existir na alegada inocência socrática tal como o concebemos na culpa do cristianismo e, nesse sentido, o tema da vontade - de matriz agostiniana - surge aqui como coluna principal da explicação kierkegaardiana do pecado. Assim, o pecado é uma enfermidade que deve ser reconhecida pelos homens. Por isso, o tema reaparece aqui no Exercício do cristianismo em outra roupagem e configuração, mas segue aprofundando os temas já postos em A Doença Mortal.

Em um tempo em que o conceito de absoluto, claramente inspirado pela matriz hegeliana, dirige-se efetivamente ao saber humano e aquilo que ele construiu de forma autônoma, parece um imenso desafio a proposta de Anti-Climacus no Exercício do cristianismo, isto é, a afirmação de que o absoluto, em realidade, não é o saber humano, mas antes reside na esfera do cristianismo, sendo este, o totalmente outro, o efetivo absoluto. Desse modo, afirma-se assim uma tese que percorrerá toda a obra kierkegaardiana, isto é, há um abismo entre o homem e Deus: "Há uma diferença infinita, abismal, entre Deus e o homem" (KIERKEGAARD, 2009, p. 85). Aos olhos do pseudonímico autor - e seguindo uma distinção aristotélica - o cristianismo talvez esteja situado entre a esfera da poesia e da história. A poesia aponta para o futuro, para aquilo que se pode imaginar e ainda não ocorreu. A história trabalha sobre os fatos ocorridos e, portanto, sobre aquilo que já passou, o já concluído. Todavia, tanto a poesia pode obscurecer o verdadeiro cristianismo quanto a história. O primeiro, a despeito de ser fascinante, pode enganar o verdadeiro significado do cristianismo na medida em que pode projetar o cristianismo como integral imaginação, tal como o pensara, por exemplo, Feuerbach. O segundo cai no típico equívoco do século XIX, que construía uma equivalência entre história e cristianismo. Por isso é enfaticamente rejeitado: “Um cristianismo histórico é bobagem e confusão anti-cristã; pois os verdadeiros cristãos que existem em cada geração não tem nada a ver com os cristãos da geração precedente, senão somente com o contemporâneo Cristo" (KIERKEGAARD, 2009, p. 86). Por isso, o cristianismo é contemporâneo não apenas para aqueles que conviveram com o Cristo em sua passagem terrena, mas para todos os cristãos e em todos os tempos. Nessa força espiritual reside a sua contemporaneidade. Dessa forma, para além da poesia e da história, "a única porta de acesso ao cristianismo é a consciência do pecado" (KIERKEGAARD, 2009, p. 88). Tal tema é fundamental em toda a filosofia kierkegaardiana e, especialmente, nas reflexões de Anti-Climacus em suas duas obras.

\section{ESCÂNDALO}

O tema por excelência da segunda parte do Exercício do cristianismo será o escândalo. Rememorando as passagens evangélicas, Anti-Climacus nos recorda a

\author{
Marcio Gimenes de Paula \\ Toledo, v. 4, n'2(2021) p. 200-218
}




\section{Aoristo)))))}

International Journal of Phenomenology, Hermeneutics and Metaphysics

frase "bem-aventurado aquele que não se escandaliza de mim". Se o tema da primeira parte acentuava-se sobre a sentença bíblica do alívio aos sobrecarregados, aqui a ênfase está claramente posta na questão do escândalo e naquilo que AntiClimacus tomara como uma exposição bíblica e uma definição de conceitos. Segundo sua compreensão, temos aqui duas categorias: a fé e o escândalo, guardando a segunda intrínseca relação com a primeira. O escândalo é sempre uma possibilidade e não se chega até a fé sem que se passe por ele.

Assim o tema do Deus-homem, típico dos Evangelhos, é apropriado pela especulação, muito ao gosto da época, como uma espécie de síntese. Desse modo, teríamos aqui a junção do aspecto divino e do aspecto humano de Cristo, resultando disso uma espécie de síntese. Mesmo que se visse a relação pelo prisma HomemDeus isso essencialmente não se alteraria, isto é, o ponto segue na questão da síntese. Contudo, Anti-Climacus, seguindo uma tradição do cristianismo mais antigo e de autores como Pascal, por exemplo, rechaça a hipótese de uma síntese e pensa o cristianismo como paradoxal: "O Deus-homem é o paradoxo, absolutamente o paradoxo; pelo que é completamente seguro que a razão tem que paralisar-se em sua proximidade" (KIERKEGAARD, 2009, p. 100).

Curiosamente, um dos aspectos centrais da exposição de toda a segunda parte do Exercício do cristianismo acentuará que o Deus-homem é a possibilidade do escândalo. Dizer que algo é "possível" é exatamente colocá-lo na esfera das coisas que não são naturais e nem necessárias. Por isso, o cristianismo, que é da esfera do espírito, afirma-se enquanto possibilidade, enquanto categoria de escolha e opção do indivíduo. Assim, não é fortuito que Anti-Climacus aqui enfatize, com bom uso de passagens dos Evangelhos e da tradição bíblica, que o escândalo é uma categoria da religião judaica de cunho mais legalista que, ao se deparar com o Deus-homem, possui dificuldades em assimilá-lo se este não realiza os feitos que tal tradição esperava. Segundo sua compreensão, "a possibilidade do escândalo relativo a Cristo qua Deus-homem durará até o final do mundo" (KIERKEGAARD, 2009, p. 109). O escândalo nunca poderá ser eliminado nem pelos ditames da religião tradicional e nem pela síntese especulativa mais moderna e sua exegese. Logo, "eliminar a possibilidade deste escândalo significa que se elimina também a Cristo, que se faz dele algo distinto do que é, sinal de escândalo e objeto de fé" (KIERKEGAARD, 2009, p. 109).

O problema revela-se ainda mais grave na medida em que o homem que se diz Deus realiza feitos miraculosos e inexplicáveis. No século XIX o milagre já não parece mais fazer parte do cristianismo da cristandade, tal como sugere Anti-Climacus: "O cristianismo da cristandade é fantasmático, tanto na orientação do milagre como na de Cristo. Na situação de contemporaneidade está colocado entre este algo inexplicável (sem que desse se siga imediatamente que se trata de um milagre) e um homem individual, que aparece como os demais - e é este homem o que realiza o inexplicável" (KIERKEGAARD, 2009, p. 113). Talvez o mesmo escândalo também já tenha existido nos tempos em que o próprio Cristo viveu entre os homens. Afinal, os Evangelhos parecem testemunhar que eram muitas as pessoas que, ao se depararem 


\section{Aoristo)))))}

International Journal of Phenomenology, Hermeneutics and Metaphysics

com os seus milagres, teriam se perguntado se aquele que fazia os milagres não era o filho de Maria e de José.

Nesse mesma senda é que Anti-Climacus aponta que a fé é, no fundo, sempre a possibilidade de escândalo. Possibilidade dada a todos os homens, inclusive aos discípulos que acompanhavam a Cristo. O que muda é a atitude dos homens em relação a ela, pois eles podem escandalizar-se e rechaçar o cristianismo, como parece, por exemplo, fazer Feuerbach e alguns dos pensadores pós-hegelianos do século XIX, ou podem acreditar, ainda que fiquem perplexos diante do escândalo. Assim, a vida do Cristo entre os homens é mais do que uma mera doutrina, por isso falar dele como "doutrina é um mal-entendido" (KIERKEGAARD, 2009, p. 121). Curiosamente, poderia haver aqui, a despeito de algumas diferenças, uma proximidade entre o pensador da Dinamarca e Nietzsche que, no seu Anticristo, também apontou que o cristianismo podia ser apenas um conjunto de incompreensões (NIETZSCHE, 2007).

Segundo o pseudonímico autor do Exercício do cristianismo, a fé cristã não pode ser algo da esfera natural ou algo adequado aos desejos do homem natural sob pena de, desse modo, perder-se a própria essência do cristianismo, que não é - e não pode ser - de ordem natural. Assim, seu Norte deve ser a felicidade eterna e não os aspectos mundanos e passageiros. Por isso, o confronto aqui é entre a tese da mundanização e do paganismo e o cristianismo e sua proposta de felicidade eterna. A rigor, a mesma questão já havia sido posta pelo pseudonímico Climacus, de um modo mais experimental, nas Migalhas filosóficas, quando se questionava se poderia haver um ponto de partida histórico para uma consciência eterna e se tal ponto de partida poderia ir além do interesse histórico e se, em decorrência disso, poderíamos construir uma felicidade eterna sobre um saber histórico.

Ao pensar sobre as determinações conceituais do escândalo, Anti-Climacus depara-se com a explicação do conceito de Deus-homem por meio da especulação espinosana, isto é, através da tese de sub specie aeterni. Contudo, não é exatamente isso o que lhe interessa, mas sim observar que o Deus-homem é um signo de contradição na medida em que Cristo não pode ser comunicado diretamente aos homens e nisso reside o escândalo.

É certo que a comunicação é um tema central não apenas aqui, mas em toda a reflexão kierkegaardiana. Por isso, aos olhos de Anti-Climacus, Cristo não pode ser comunicado de maneira direta, visto ser um signo de contradição: "Está visto que a comunicação direta é uma impossibilidade para o Deus-homem, posto que sendo signo de contradição não pode comunicar-se diretamente..." (KIERKEGAARD, 2009, p. 138).

Desse modo, uma das maneiras escolhidas pelo Deus-homem para comunicarse é através da figura do servo incógnito, presente em toda a tradição judaico-cristã. Boa parte das reflexões do século XIX vai exatamente na mão contrária, isto é, elimina qualquer aspecto incognoscível da figura divina. Assim, mesmo a figura de Deus passa a ser um objeto completo cognoscível pelos homens. Contudo, quando Deus toma a forma humana, e ele próprio confunde o que é humano com aquilo que é divino, ele está construindo a sua incognoscibilidade, fato que a modernidade

$$
\begin{array}{r}
\text { Marcio Gimenes de Paula } \\
\text { Toledo, v.4, n`2(2021) p. 200-218 }
\end{array}
$$




\section{Aoristo)))))}

International Journal of Phenomenology, Hermeneutics and Metaphysics

parece negar. Por isso, o poeta português Fernando Pessoa talvez esteja certo quando afirmou que Deus não desejo revelar-se plenamente e, portanto, muito da nossa teologia é, na verdade, um exercício de infidelidade ${ }^{5}$. Assim, a infinita distância qualitativa entre Deus e o homem acaba também por ser extinta, o que parece inaceitável aos olhos do autor do Exercício do cristianismo.

Segundo Anti-Climacus, o confronto entre comunicação direta e comunicação indireta mostra que apenas um ídolo pode ser comunicado diretamente, mas não o Deus da herança judaico-cristã. Nisso, inclusive, residiria um conceito central da filosofia kierkegaardiana, isto é, o conceito de seriedade: “A cognoscibilidade direta é precisamente a característica do ídolo. Mas agora se faz o mesmo com Cristo, e isto em virtude de seriedade..." (KIERKEGAARD, 2009, p. 146).

A comunicação indireta de Cristo está diretamente relacionada com o mistério do seu sofrimento. No cristianismo dos primórdios o sofrimento era parte constitutiva da essência do cristianismo. Curiosamente, com o passar dos anos, o sofrimento acaba por ser banido do cristianismo. Nesse particular, a tese kierkegaardiana encontra-se com a interpretação de Feuerbach, que também pretende estudar o cristianismo nas suas origens visto que, no seu entender, o cristianismo moderno apresenta apenas um pobre testemunho do autêntico cristianismo: "O cristianismo moderno não pode apresentar mais nenhum testemunho a não ser testimonia paupertatis. O que ele ainda possui não possui de si, vive de esmolas dos séculos passados" (FEUERBACH, 1997, p. 20).

Negar a comunicação direta é, na verdade, afirmar a fé. Reconhecer a existência da possibilidade do escândalo para a constituição da fé. Por isso, a recusa da comunicação direta implica no reconhecimento da diferença qualitativa entre o homem e Deus e, ao mesmo tempo, traz novamente à tona o conceito de seriedade, tão caro para as reflexões kierkegaardianas. Em outras palavras, negar a comunicação direta no âmbito do cristianismo significa, aos olhos de Anti-Climacus, instaurar a verdadeira seriedade, que havia sido perdida. A filosofia moderna, ao contrário, parece que preferiu acreditar no imediato, e com tal coisa equivocou-se: "Mas toda a filosofia moderna nos fez crer com o seu empenho que a fé é uma determinação imediata, é o imediato, com o qual está novamente ligado o fato da eliminação da possibilidade do escândalo..." (KIERKEGAARD, 2009, p. 150). O fim do escândalo no cristianismo é precisamente a vitória do paganismo. Assim, quem elimina a fé, elimina também o escândalo.

\section{MAJESTADE DIVINA}

A terceira parte do Exercício do cristianismo usa como mote uma citação de João 12,32 ("E eu, quando for levantado da terra, todos atrairei a mim”) e divide-se em sete partes, todas usando exatamente o mesmo título da passagem bíblica, uma repetição muito ao gosto daquilo que apreciava Kierkegaard, que também repetiu

\footnotetext{
${ }^{5}$ A tese de Fernando Pessoa aparece sob a pena do heterônimo Alberto Caieiro no célebre poema $O$ Guardador de Rebanhos: "Pensar em Deus é desobedecer a Deus, Porque Deus quis que o não conhecêssemos, Por isso se nos não mostrou..." http://arquivopessoa.net/textos/1485 Acessado em 16.12.2020.
} 


\section{Aoristo)))))}

International Journal of Phenomenology, Hermeneutics and Metaphysics

títulos de Discursos Edificantes com reflexões diversas. Aliás, deve-se destacar que a reflexão da primeira parte é, na verdade, um sermão feito pelo Magister Kierkegaard em 1848, tal como ele mesmo aponta em nota de rodapé explicativa ${ }^{6}$. De igual modo, tal como em outros capítulos, destaca-se que o autor inicia por uma oração, como também costuma ocorrer nos chamados Discursos Edificantes.

A reflexão principia pela afirmação de que a vida do cristão se orienta pelo Deus que está no mais alto céu. Em outras palavras, Anti-Climacus começa pontuando exatamente num tempo onde a diferença entre Deus e homem parecia diminuir ou mesmo se extinguir totalmente, a separação radical entre Deus e o homem. Contudo, tal separação não significaria que o Deus não se importasse com o homem, mas antes o atrairia a si. O erro seria o homem, por sua própria conta e a partir da sua vida terrena, tentar elevar-se a Deus. Assim, a vida do cristão orienta-se pelo Deus que está no alto, mas não no sentido de alcançá-lo por si mesmo.

O cristianismo pede dos homens que exercitem a sua memória, pois eles devem recordar-se do Deus eterno e se esquecerem das coisas mundanas e passageiras. Nesse sentido, precisam deixar de lado suas vaidades e a sua melancolia na medida em que ambas parecem se relacionar a aspectos do eu do homem e à falta de sentido, coisas que o cristianismo deseja superar.

Entretanto, o cristianismo não deseja se apartar do eu em si, mas do eu mundano e natural. $\mathrm{O}$ eu como aspecto da consciência é de fundamental importância na reflexão cristã pois, segundo a tese kierkegaardiana, é a partir do eu que se alcança a consciência do pecado, tema que aparece aqui destacado e com o qual AntiClimacus já havia trabalhado em A Doença Mortal. Deste modo, o cristianismo deve exercer uma atração numa espécie de duplo movimento: a si e para Deus. Por isso, Anti-Climacus pode questionar-se sobre o que significa ser um eu: "O que significa ser um eu? Significa que se é uma duplicidade (KIERKEGAARD, 2009, p. 167). O eu do homem é objeto de reflexão, é da esfera do espírito. Por isso, quando Deus o atrai faz muito mais do que o imã faz com o ferro, pois nele o que ocorre é uma atração que pode ser explicada pelas leis da física. Logo, "o eu é uma duplicidade, é liberdade" (KIERKEGAARD, 2009, p. 167). Assim, entra no jogo dialético a escolha humana que, a rigor, não existia no âmbito da relação física. Ou seja, "quando é atraído o ferro não há e nem pode falar-se de nenhuma eleição" (KIERKEGAARD, 2009 , p. 167). Deste modo, deparamo-nos aqui com um tema dos mais antigos da tradição cristã, presente desde a era apostólica e nas reflexões de inúmeros autores como, por exemplo, Santo Agostinho. O tema do eu e da consciência sem o qual, a rigor, não se pode falar do cristianismo.

Se ocorre uma atração, isto é, se o Deus do céu atrai o homem até si, cabe uma pergunta sobre como é este tipo de atração e por quem ela é efetivamente exercida. Aqui Anti-Climacus dedica-se a explicar que o Cristo, que atrai os homens até si, é na verdade a figura do sofredor. Não é a figura do Deus majestoso no sentido de algo que está apartado do cotidiano dos homens ou inacessível a eles. Antes viveu entre

\footnotetext{
${ }^{6}$ Nota 1 da página 159 da edição espanhola, que utilizamos aqui.
} 


\section{Aoristo)))))}

\section{International Journal of Phenomenology, Hermeneutics and Metaphysics}

eles, tomou forma humana e ao identificar-se com o sofrimento no seu mais alto grau termina por incluir todos os homens, por isso o papel do Deus humilhado é fundamental na construção da dialética entre o Cristo humilhado e o Cristo exaltado: "Se o humilhado não tivera vivido não saberíamos nada do exaltado; e se o humilhado não tivera dito estas palavras não teríamos sabido certamente nada acerca de que Ele atrairia a todos desde as alturas" (KIERKEGAARD, 2009, p. 168-169).

Há dois aspectos a se destacar a na dialética do Cristo humilhado. Além dele incluir a todos em tal situação, pode-se destacar aqui que o Cristo humilhado representa um desafio, pois todos parecem gostar e se aproximar do Cristo exaltado, do Cristo com poder e glória. Contudo, tal aproximação não revela um sentimento autêntico, mas antes mostra um sentimento interesseiro, pois é bom e vantajoso estar ao lado de quem tem poder, de quem pode nos oferecer algo. Assim, aquele que segue o Cristo humilhado coloca-se ao lado de um Deus que nada pode lhe oferecer nesse sentido, por isso seu sentimento parece ser o mais autêntico.

A humilhação do Cristo não é sem propósito e nem sem objetivo. Ela ocorre por amor aos homens. Para que todos possam ser incluídos e para que todos o possam autenticamente seguir. Não é nenhum espetáculo estético ou ato mirabolante, mas um ato da paixão do Cristo pelos homens. Seu movimento é feito por amor. A mesma descrição feita aqui minuciosamente num tom mais claro e assumidamente edificante, já fora apontada por outro pseudônimo de Kierkegaard. Nas Migalhas filosóficas, em tom mais conceitual, Climacus constrói exatamente o mesmo tipo de explicação para a ação do deus (ali em letras minúsculas seguindo o modo grego) em direção ao homem: seu movimento ocorre por amor. Tal fato igualmente foi melhor elucidado num tom edificante nas Obras do amor de 1847 (KIERKEGAARD, 2005), onde Kierkegaard claramente explicita a diferença entre o amor no cristianismo e no paganismo, enfatizando ainda o dever de amar do cristianismo em detrimento da posição grega do amor de predileção.

Um dos discursos que, talvez, mais mascare a realidade do cristianismo é, aos olhos de Anti-Climacus, aquele que se preocupa apenas em exaltar a glória divina. $\mathrm{O}$ Cristo exaltado e no mais alto céu só pode fazer sentido se for visto, dialeticamente, ao lado do Cristo humilhado e rebaixado, ou seja, eles não podem ser vistos separadamente. Nesse sentido, a vida do Cristo é vista como uma espécie de militância e de prova testemunhal de quem ele representa, sendo mais forte do qualquer doutrina que possa ser construída a posteriori.

É certo que os homens possuem a memória, a imaginação e neles atua a força de ambas. Tanto memória como imaginação são aspectos centrais no cristianismo e sua força ajuda na constituição dessa concepção. Contudo, ao mesmo tempo, a memória humana se enfraquece com o passar dos anos e pode não ser mais tão confiável como o era nos primórdios. A imaginação também pode se confundir e misturar elementos, o que também seria problemático. Assim, o cristianismo não pode depender somente da memória e da imaginação ainda que elas possam ser muito importantes. Aos olhos de Anti-Climacus o principal problema residiria no fato de que o aperfeiçoamento humano da compreensão de memória e imaginação tende a abrandar e mesmo retirar do cristianismo um aspecto que lhe é essencial, a saber, o 


\section{Aoristo)))))}

International Journal of Phenomenology, Hermeneutics and Metaphysics

sofrimento. Por isso, os problemas com um cristianismo meramente histórico e totalmente dependente da memória, pois ele tenderia a diminuir a ênfase na prática e no testemunho da verdade. A concepção kierkegaardiana sempre apontou, com muita clareza, que o cristianismo não pode ser natural, por isso está ligado a uma espécie de segunda natureza humana e aqui o aspecto da vontade é central. Logo, ele também não pode ser assimilado plenamente de modo cultural e social.

Desde as Migalhas filosóficas, onde o pseudonímico Climacus constrói as coisas de modo mais conceitual, a ideia de testemunho é central. Contudo, testemunho deve ser visto aqui em clara referência ao seu sentido grego, isto é, "martírio", algo que resulta em poder até mesmo morrer por uma causa ou uma ideia, como o fizeram os primeiros mártires do cristianismo dos primórdios e alguns filósofos. Contudo, diferentemente do que talvez pensaram Feuerbach e Nietzsche, que viam na humilhação do cristão uma espécie de exaltação às avessas, Anti-Climacus é aqui categórico em afirma-la: "A humilhação do verdadeiro cristão não é simples e claramente a humilhação, é somente um reflexo da elevação, mas um reflexo neste mundo, em que a elevação tem que manifestar-se contrastando-se com pequenez e humilhação" (KIERKEGAARD, 2009, p.200). Assim, a humilhação do cristão talvez nunca possa ser efetivamente compreendida - e nem parece ser de tal ordem - neste mundo.

Se o martírio é central no cristianismo exposto por Anti-Climacus, seu tema é claramente o tema da Igreja militante em oposição ao da Igreja triunfante, tal como já também o fizera o pseudonímico Climacus no Pós-Escrito às Migalhas filosóficas. Logo, estamos novamente às voltas com a discussão sobre o Deus-homem, tema central na reflexão cristã e no pensamento kierkegaardiano. Talvez seja ilustrativa aqui a lembrança feita por Anti-Climacus da cena bíblica de Cristo diante de Pilatos. Ali, segundo a narrativa dos Evangelhos, percebe-se não apenas a presença do Deushomem diante da autoridade romana, mas a pergunta feita por Pilatos a Cristo sobre em que consistia a verdade. Curiosamente, Cristo, que era a verdade, não se denominou assim diante dele e nem se atreveu a dar-lhe uma definição cabal do que seria a verdade: "Pois o que é a verdade? E em que sentido era Cristo a verdade? A pergunta a fez Pilatos como era sabido, uma segunda pergunta é se a ele lhe importava muito ou nada conseguir resposta a esta pergunta..." (KIERKEGAARD, 2009, p.204).

A pergunta pela verdade sempre foi perseguida pela filosofia e, para quem acompanha a reflexão kierkegaardiana, percebe o quanto ela é importante já nas Migalhas filosóficas e no Pós-Escrito às Migalhas filosóficas. Por isso, aprofundando sua reflexão, agora sob a pena de Anti-Climacus, pode-se perceber que a tese kierkegaardiana questiona-se se a verdade pode ser tomada como um saber (aqui mais objetivo e científico) ou se ela deve ser percebida como uma espécie de caminho, de algo em construção, de um devir, de um vir a ser do indivíduo: "Cristo era a verdade, era o caminho, no sentido de que a verdade é o caminho" (KIERKEGAARD, 2009, p.209). A pista é extremamente instigante para percebermos a riqueza da subjetividade kierkegaardiana, isto é, a verdade enquanto apropriação

$$
\begin{array}{r}
\text { Marcio Gimenes de Paula } \\
\text { Toledo, v. 4, n*2(2021) p. 200-218 }
\end{array}
$$




\section{Aoristo)))))}

\section{International Journal of Phenomenology, Hermeneutics and Metaphysics}

de um ser em caminho, de um vir a ser, de um devir. Assim, a riqueza da subjetividade parece adquirir outros contornos.

A discussão sobre a verdade é igualmente fundamental para perceber a crítica construída no Exercício do cristianismo ao conceito de Igreja triunfante. É um ponto a perceber que a Igreja triunfante é aquela que tem êxito na sociedade e firma-se, sobretudo, com a vitória e oficialização do cristianismo no Império Romano sob o domínio de Constantino. Em outras palavras, a verdade do cristianismo desloca o seu eixo, isto é, ela sai da esfera do espiritual, do subjetivo e do martírio para a esfera da plena aceitação social e do domínio político. O cristianismo passa a ser, portanto, imperial. Nesse sentido, verdade não é mais algo a ser apropriado, mas a verdade do cristianismo passa a ser impor pela força do poderio político.

Neste escopo é que se pode compreender uma importante tese kierkegaardiana: Jesus Cristo não é - e não pode ser - uma espécie de pensador, tal como avaliava uma dada leitura histórica e intelectual da religião cristã no século XIX: "Se Cristo tivesse sido desta maneira, por exemplo, um mestre da verdade, um pensador que tinha feito um descobrimento ou esquadrinhado algo que quiçá lhe custara indescritíveis dores de cabeça, mas que dessa maneira também podia converter-se em resultado... (KIERKEGAARD, 2009, p. 210). Em outras palavras, ele é muito mais do que um resultado ou um líder intelectual de uma determinada doutrina.

O conceito de Igreja triunfante termina por negar a própria essência cristã na medida em que nega a subjetividade ou, no máximo, a reconhece num segundo plano, isto é, abaixo do domínio político e social. Igualmente nega a apropriação do cristianismo e o devir cristão de cada indivíduo. Em outras palavras, termina por negar a agonia e o combate internos constituintes do próprio cristianismo, como bem percebeu Miguel de Unamuno (2017), um leitor muito atento das teses kierkegaardianas. Assim, a cristandade seria a representante por excelência da Igreja triunfante ao passo que o cristianismo subjetivo estaria contemplado na Igreja militante. Aqui percebe-se, com imenso vigor, um tema que será fundamental não apenas na reflexão kierkegaardiana mas, quiçá, será igualmente importante na reflexão da filosofia da existência inspirada pelo autor dinamarquês - entre outros tantos fatores - e repercutirá no século XX: o conceito de autenticidade.

O cristianismo é, portanto, mais do que história e mais do que doutrina, mas é fortemente marcado pela ideia da prática, como bem mostra o próprio título da obra de Anti-Climacus, isto é, a ideia de um exercício, como também já havia pensado Kierkegaard nas Obras do Amor. Por isso, o tema da interiorização é também fundamental, isto é, o tornar-se cristão, o aspecto subjetivo da fé. Desse modo, AntiClimacus é categórico em afirmar a verdade, sob estas condições, da Igreja militante: "Somente a Igreja militante é verdade, a verdade é que enquanto a Igreja perdure neste mundo é a Igreja militante, que se relaciona com Cristo na sua humilhação, ainda que seja atraída por sua majestade" (KIERKEGAARD, 2009, p. 229).

Se o cristianismo - no decorrer de sua história - depende de aspectos objetivos e se afirma categoricamente na subjetividade, Anti-Climacus avalia que a pregação cristã, por exemplo, deve ser algo mais do que uma mera consideração. Ela deve antes estimular um conceito fundamental para Kierkegaard e boa parte da tradição 


\section{Aoristo)))))}

International Journal of Phenomenology, Hermeneutics and Metaphysics

cristã, que é o conceito de imitação de Cristo: "Na cristandade todavia se ouvem com frequência sermões, conferências, discursos acerca do que se exige a um imitador de Cristo, em que consiste ser um imitador de Cristo, que significa imitar a Cristo e coisas parecidas" (KIERKEGAARD, 2009, p. 230). Contudo, trata-se aqui não efetivamente de algo da esfera prática ainda, mas o conceito de imitação da cristandade é o conceito intelectual, o que soa estranho na medida em que a imitação, do ponto de vista cristão, ocorre na esfera da atuação prática da vida.

A própria pregação cristã merece, no contexto da cristandade ser questionada, isto é a quem prega efetivamente o pregador? Sua fala é uma peça retórica, intelectual, acadêmica ou busca a edificação e a admoestação necessária ao autêntico cristianismo? Nesse sentido, Anti-Climacus muito oportunamente lembra que talvez, por esse motivo, Cristo tenha tido vários admiradores - e talvez ainda os tenha - mas poucos imitadores. A admiração é da esfera estética, ao passo que o cristianismo implica aspectos éticos, morais e, por isso, está no reino da interioridade e do subjetivo. Curiosamente, até mesmo o traidor Judas foi um admirador da figura de Cristo, ou melhor, "porque era um admirador se transformou com toda a correção em traidor" (KIERKEGAARD, 2009, p. 241). Também Nicodemos, com suas dúvidas, parece estar na mesma condição de admirador. Assim, tal é a definição cabal de nosso autor: “Somente o 'imitador' é o verdadeiro cristão. O 'admirador' propriamente comporta uma relação pagã até o cristianismo; e por isso a admiração também deu à luz no meio da cristandade um novo paganismo: a arte cristã" (KIERKEGAARD, 2009, p. 248)7. Contudo, ainda que Anti-Climacus faça vigorosa crítica ao admirador do cristianismo e contraponha a este, como verdadeiro cristão, o imitador, a conclusão que ele chega, em seu tempo, é de que até mesmo os admiradores do cristianismo escassearam. Assim até mesmo "um admirador do cristianismo é coisa rara..." (KIERKEGAARD, 2009, p. 250). Curiosamente, nas páginas seguintes - e com propósito preciso - ele repete três vezes a mesma sentença: "Mas o admirador no sentido mais rigoroso não é certamente o verdadeiro cristão, somente o é o imitador" (KIERKEGAARD, 2009, p. 251). Por isso, a obra termina, em suas últimas páginas, com um grande prece onde se reconhece a distância abismal entre o homem e Deus e onde se tenta perceber com vigor a essência cristã.

\section{CONCLUSÃO}

Em seu artigo Kenosis and Offense: a Kierkegaard look at Divine Transcendence, Merold Westphal aponta que, no Exercício do cristianismo, haveria um lado fortemente luterano em Kierkegaard: “Kierkegaard é em muitos aspectos simplesmente um bom luterano. A distinção entre o humilhado e rebaixado Jesus com quem nós podemos nos tornar contemporâneos e o exaltado e glorificado Cristo com quem nós não

\footnotetext{
${ }^{7}$ A crítica feita aqui por Kierkegaard à arte cristã no contexto da cristandade mereceria uma maior atenção e cuidado, visto que o pensador trabalhava muito detidamente com conceitos artísticos. Assim, não vale a pena fazer conclusões apressadas ou superficiais. Por isso, optamos por apenas fazer menção ao fato, deixando em aberto uma avaliação mais precisa.
} 


\section{Aoristo)))))}

International Journal of Phenomenology, Hermeneutics and Metaphysics

podemos, já que ele ainda não veio em sua glória, ecoa a theologia crucis do Catecismo de Heidelberg de 1518..." (PERKINS, 2004, p. 19).

Tal distinção, luterana por excelência, igualmente fará o pensamento de Kierkegaard ecoar com toda a força nas reflexões de Karl Barth (2016), teólogo calvinista do século XX que, especialmente na sua Carta aos Romanos, mostra-se claramente influenciado pela leitura de Kierkegaard e pelo seu modo de conceber o cristianismo, como bem percebe Spoheim em seu artigo Relational Transcendence in Divine Agency: "Na teologia subsequente este tema da transcendência de Deus foi celebrado notoriamente por Karl Barth em seu comentário aos Romanos. Este tema sempre foi entendido como representando uma antítese à visão de Deus que enfatiza o relacionamento genuíno com o humano" (PERKINS, 2004, p. 47).

Desse modo temos aqui, numa obra que parece ser uma mera exposição do cristianismo num tempo em que ele era tão criticado como no século XIX, um autor que conhece bem a herança clássica grega, a herança clássica cristã e os temas centrais tanto da reflexão católica como da reflexão protestante. Talvez possa soar estranho - e mesmo inaceitável para alguns - que haja no Exercício do cristianismo algo de "apologético" na medida em que o próprio pseudônimo Anti-Climacus, na Doença Mortal, recusara qualquer apologética ao dissertar acerca do cristianismo. Contudo, não se trata de mera "apologética" banal do cristianismo, mas de uma resposta e de uma alternativa ao debate como, talvez por outras vias, já apresentara Schleiermacher, ainda no século XVIII, ao construir o seus diálogos Sobre a religião que, não fortuitamente, levava o significativo subtítulo discursos a seus menosprezadores cultivados (SCHLEIERMACHER, 1990).

Assim, Kierkegaard parece reconstruir, com o linguajar filosófico do século XIX, uma tradição existente do cristianismo desde os primórdios, isto é, a apologia e o debate com as teses pagãs (ou anticristãs). O mesmo se poderá perceber em pensadores da tradição patrística como Orígenes, Clemente de Alexandria, Basílio de Cesareia e Agostinho de Hipona, dentre tantos outros. O pensador dinamarquês, talvez ao modo de uma Hannah Arendt que, no século XX, se recusava ser chamada de "filósofa" e praticava reflexão filosófica, quiçá, por um desgaste dos próprios conceitos, tenha se recusado ao título de "apologeta" na medida em que este, tal como o próprio título de "cristão", já não parecia valer mais nada. Talvez pelo mesmo motivo ele também havia recusado o nome de "cristão" nos seus escritos finais.

Entretanto, seria extremamente ingênuo não notar que o Exercício do cristianismo é, no fundo, uma grande resposta aos pós-hegelianos críticos da religião, especialmente uma resposta a Feuerbach, como tentamos articular em alguns dos momentos do nosso trabalho aqui exposto. Contudo, como bem percebeu Berry no seu artigo Practicing Liberation: Feminist and Womanist Dialogues with Kierkegaard's Practice in Christianity, "[...] Exercício do cristianismo é endereçado à cristandade como poder estabelecido" (PERKINS, 2004, p. 339).

Mas como pode ocorrer tal resposta? Kierkegaard, apesar de trabalhar como conceitos e ser um pós-hegeliano típico (talvez a "contragosto"), recusa o âmbito 


\title{
Aoristo)))))
}

International Journal of Phenomenology, Hermeneutics and Metaphysics

moderno de transformar religião em filosofia e, por isso, como bem aponta Nepi, escolhe outra alternativa:

O grande enigma de Cristo representa então, ao longo de toda a obra kierkegaardiana, o fio condutor para um repensar crítico de alguns resultados filosóficos próprios da modernidade, culminados na pretensão de reduzir também a fé ao saber. O Cristo da fé ao Cristo da filosofia, a redenção do mal radical a progresso totalmente horizontal de emancipação do homem. Cristo é então para Kierkegaard a verdadeira pedra de tropeço da filosofia, o sintoma do seu caráter de saber não conclusivo e incompleto, e da exigência para o homem de recorrer a uma dimensão ulterior no que se refere às pretensões totalizantes da razão" (NEPI, 1992, p. 33).

Tal percepção do Exercício do cristianismo talvez possa nos auxiliar a percebê-la no horizonte dos debates da filosofia da religião no século XIX, o que pode torna-la significativa tanto do ponto de vista da filosofia como da teologia, inserindo-a no âmbito maior de obras dos grandes pensadores da tradição cristã e do século XIX.

\section{REFERÊNCIAS}

BÍBLIA Online: https://www.bibliaonline.com.br/acf. Acessado em 16,12,2020.

BULTMANN, R. Demitologização - Coletânea de ensaios. São Leopoldo: Sinodal, 1999.

FEUERBACH, L. A Essência do cristianismo. Campinas: Papirus, 1997.

KEMPIS, T. Imitação de Cristo. São Paulo: Quadrante, 1987.

KIERKEGAARD, S.A As Obras do Amor- algumas considerações cristãs em forma de discursos.

Petrópolis: Vozes, 2005.

Ejercitación del cristianismo. Madrid: Trotta, 2009.

Esercizio del Cristianesimo. Roma: Studium, 1971.

Indøvelse i Christendom. Reitzel: København, 1850.

Kierkegaard's Journals and Papers - 6 vol. Bloomington: Indiana University Press, 1967-1978.

L'École du Christianisme. Paris : L'Orante, 1963.

Migalhas filosóficas. Petrópolis: Vozes,1995.

Pós-Escrito às Migalhas filosóficas v I-II. Petrópolis: Vozes, 2013.

Practice in Christianity. Princeton: Princeton University Press,1991.

O Conceito de angústia. Petrópolis: Vozes, 2010.

LOYOLA, I. Exercícios espirituais. São Paulo: Loyola, 2000.

NEPI, P (org). L'esercizio del cristianesimo di Kierkegaard e il Cristo dei filosofi. Torino: Paravia, 1992.

NIETZSCHE, F. Anticristo: maldição ao cristianismo e Ditirambos de Dionísio. São Paulo: Companhia

das Letras, 2007.

PERKINS, R (ed.). International Kierkegaard Commentary vol. 20 - Practice in Christianity. Macon:

Mercer University Press, 2004.

PESSOA, F. O Guardador de Rebanhos. http://arquivopessoa.net/textos/1485 Acessado em

16.12.2020.

SCHELEIERMACHER, F.D.E. Sobre la religión. Madrid: Tecnos, 1990.

UNAMUNO, M. A Agonia do cristianismo. Curitiba: Danúbio, 2017.

\author{
Marcio Gimenes de Paula \\ Toledo, v. 4, n'2 (2021) p. 200-218
}




\section{Aoristo)))))}

International Journal of Phenomenology, Hermeneutics and Metaphysics

Submetido: 10 de junho de 2021

Aceito: 10 de julho de 2021 